\section{Low Temperature Is Critical for Jujube Grafting Success in Frost-prone Northern New Mexico}

\author{
Shengrui $\mathrm{YaO}^{1}$
}

ADDITIONAL INDEX WORDs. environmental factors, grafting method, Ziziphus jujuba, Ziziphus spinosa

SumMary. The increased popularity of jujube (Ziziphus jujuba) combined with the difficulty of grafting have limited supplies of grafted trees in the United States. From 2011 to 2020 , grafting was practiced for cultivar amplification after importation and cultivar trials in frost-prone northern New Mexico. Grafting success was related to not only grafting techniques but also climate factors. Bark grafting, whip/tongue grafting, and cleft grafting were commonly used in nurseries. Low temperatures had a critical role in jujube grafting success in marginal regions and were more important than the grafting technique. If frost occurs before or near the leafing time, then grafting should be delayed until the rootstocks are determined to be healthy and alive. If frost occurs after grafting, then grafting failure and/or thin and small plant percentages increased. If only branchlets appear after grafting, then pinching branchlets could stimulate new shoot growth.

$\mathrm{J}$ ujube (Ziziphus jujuba), a deciduous fruit tree grown in China for more than 4000 years, bears very hutritious fruit that have been consumed as food and widely used in traditional Chinese medicine (Yao, 2013). Jujube is gaining popularity with commercial growers and home gardeners in the United States because of its low maintenance requirements, nutritious and tasty fruit, and health benefits. However, as the demand for jujube trees steadily increases, the tree supply from nurseries is becoming a limiting factor. Jujube tissue culture propagation is progressing (Y. Chang, personal

Received for publication 3 Aug. 2021. Accepted for publication 26 Oct. 2021

Published online 14 December 2021.

${ }^{1}$ Department of Plant and Environmental Sciences, Sustainable Agriculture Science Center at Alcalde, New Mexico State University, Alcalde, NM 87511

I thank Gill Giese and Robert Heyduck from New Mexico State University for their critical review of this manuscript before submission. I thank the anonymous reviewers for their comments/suggestions regarding the previous version of this manuscript. I acknowledge Bingye Xue of Chinese Red Date Orchard for providing some grafting data and reviewing this manuscript.

This project was partially supported by a Specialty Crop Block Grant through the New Mexico Department of Agriculture, Hatch funds from the U.S. Department of Agriculture National Institute of Food and Agriculture, and the New Mexico State University Agricultural Experiment Station.

S.Y. is the corresponding author. E-mail: yaos@ nmsu.edu.

This is an open access article distributed under the CC BY-NC-ND license (https://creativecommons. org/licenses/by-nc-nd/4.0/).

https://doi.org/10.21273/HORTTECH04927-21 communication), but grafting is still the dominant propagation method.

Jujube grafting became popular in China in the 1980s. Before then, suckers (small plants from mother plants with root attached) collected from established jujube trees were commonly used for new plantings (Guo and Shan, 2010). Bark grafting, cleft grafting, side grafting, and whip/tongue grafting have been popularly used in nurseries in China (Guo et al., 1994; Shi et al., 2006; Wu et al., 2018). Bark grafting and cleft grafting were common in top-working to change cultivars $(\mathrm{Li}, 2009)$. People in rural areas also graft jujube cultivars to sour jujube (Ziziphus spinosa) in the wild to increase productivity (Wang, 2014). Compared with traditional jujube-producing provinces, grafting in place was more popular than planting grafted trees in the newly emerged jujube production areas such as Xinjiang in China (Chai et al., 2016; Ma et al., 2019). There are hundreds of publications about jujube grafting in China, with the majority being popular science reports or experience summaries. Published research of this topic is limited $(\mathrm{Li}$, 2009; Shi et al., 2006; Wu et al., 2018). In the United States, an extension publication about jujube grafting was published in 2014, and it included a grafting video link (Yao, 2014). A similar extension publication was published in western Australia (Johnstone, 2020).

The jujube program at the New Mexico State University (NMSU) Sustainable Agriculture Science Center in Alcalde, NM, started in 2010. In Spring 2011, the imported scionwood from China was grafted onto sour jujube rootstocks. Then, different types of grafting techniques were used for imported cultivar amplification, cultivar propagation for cultivar trials, top-working, or other reasons. This report is a summary of the successes and problems during 10 years of grafting experience and a discussion of the effects of environmental factors on grafting in Alcalde, NM.

\section{Materials and methods}

ScIONWOOd SELECTION. Oneyear-old primary shoots were the main source of scionwood for all cultivars $(Y a o, 2014)$. If there was a shortage of scionwood for some cultivars, then the basal one or two nodes of side branches or 2-year-old branches were used as scionwood. Shoot diameters of $\approx 0.3$ inches or larger were preferred. Branches with a diameter of 0.5 inches or larger were difficult to cut and use for grafting, but occasionally they were used for whip/tongue grafting. Scionwood was collected during mid to late March, waxed, and stored at $40{ }^{\circ} \mathrm{F}$.

Rоoтsтоскs. Sour jujube seedlings were used as jujube rootstocks. Sour jujube fruit were collected during September of each year. After collection, fruit were soaked and flesh was removed, and seeds were cleaned and dried. Stratification is not necessary for

\begin{tabular}{llll}
\hline $\begin{array}{l}\text { Units } \\
\text { To convert U.S. to SI, } \\
\text { multiply by }\end{array}$ & U.S. unit & SI unit & $\begin{array}{l}\text { To convert SI to U.S., } \\
\text { multiply by }\end{array}$ \\
\hline 0.2366 & $\mathrm{cup}(\mathrm{s})$ & $\mathrm{L}$ & 4.2268 \\
0.3048 & $\mathrm{ft}$ & $\mathrm{m}$ & 3.2808 \\
2.54 & inch $(\mathrm{es})$ & $\mathrm{cm}$ & 0.3937 \\
0.4536 & $\mathrm{lb}$ & $\mathrm{kg}$ & 2.2046 \\
14.7868 & tablespoon $(\mathrm{s})$ & $\mathrm{cm}^{3}$ & 0.0676 \\
$\left({ }^{\circ} \mathrm{F}-32\right) \div 1.8$ & ${ }^{\circ} \mathrm{F}$ & ${ }^{\circ} \mathrm{C}$ & $\left({ }^{\circ} \mathrm{C} \times 1.8\right)+32$
\end{tabular}


jujubes, but stratification can facilitate germination. Experience has shown that dry sour jujube seeds are still viable 3 years after collection.

Seeds were fully soaked for 2 to $3 \mathrm{~d}$ before seeding, or they were seeded in potting mix in trays and then transplanted to the field when they were 2 to 3 inches in height. Seeds were sown during late April to early May each year in Alcalde, NM, with an average of 150 frostfree days (lat. $36^{\circ} 05^{\prime} 27.94^{\prime \prime} \mathrm{N}$, long. $106^{\circ} 03^{\prime} 24.56^{\prime \prime} \mathrm{W}$, elevation $1730 \mathrm{~m}$ ).

After 1 or 2 years of growth in the field, sour jujube seedlings were ready for grafting. The soil was Fruitland sandy loam (coarse-loamy, mixed, calcareous, mesic Typic Torriorthents) (U.S. Department of Agriculture, 2008). The field was irrigated with drip irrigation (twice per week) or flood irrigation (once per week). Fertigation $(24 \mathrm{~N}-3.5 \mathrm{P}-13.3 \mathrm{~K})$ was applied through drip irrigation at $2 \mathrm{lb} /$ $200 \mathrm{ft}$ of row, three to four times per year, from June to July. For flood-irrigated plots, urea and complete fertilizer $(13 \mathrm{~N}-5.7 \mathrm{P}-10.8 \mathrm{~K}$ or others; applications varied from year to year) were applied at $\approx 4$ to $5 \mathrm{lb} / 200 \mathrm{ft}$ of row. Seedlings were also fed dissolved $24 \mathrm{~N}-3.5 \mathrm{P}-13.3 \mathrm{~K}$ fertilizer at a rate of 1 tablespoon/gal, 2 cups/plant, two to three times per season. Seeding beds were $6 \mathrm{ft}$ apart, with double rows in the middle of the beds $1 \mathrm{ft}$ apart. Plants were $2 \mathrm{ft}$ apart in rows and staggered between rows.

Grafting Methods. Depending on rootstock and scionwood size, bark grafting, whip/tongue grafting, or cleft grafting was used (Fig. 1). Whip/ tongue grafting was mainly used for smaller rootstocks and required size matching for rootstock and scionwood. Cleft grafting was applied on relatively

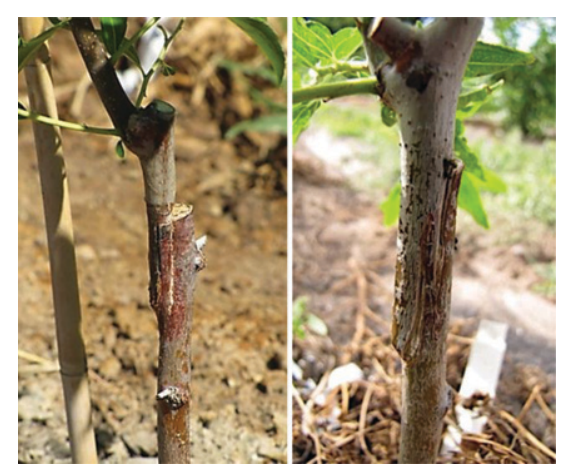

Fig. 1. Jujube bark grafting (left) and whip/tongue grafting (right). larger rootstocks. Because the seedling rootstocks were not uniform and varied in size from bed to bed and year to year, the grafting methods used depended on the size of each rootstock and available scionwood.

The grafting dates varied from mid to late May, when the rootstock's new growth was typically $\approx 1$ to 1.5 inches in length. In 2014, with severe late frost before grafting, the grafting was delayed to late May to early June. In 2020 , there was a frost after grafting, and another round of grafting took place in mid-June.

Grafting take rates were counted 4 or 5 weeks after grafting and again in late July/August. A final count was performed in the fall. Large plants and small plants (3-4 and $1-3 \mathrm{ft}$ in height, respectively) were counted separately.

After grafting, new growth on the rootstocks was removed two to three times at 14-d intervals. The new shoots from scionwood were supported by 4 - $\mathrm{ft}$ bamboo stakes when they reached 6 to 8 inches. New shoots were tied to sticks with a plant tie stapler as they grew.

From 2011 to 2020, grafted plants were used for cultivar propagation, cultivar trials at NMSU (Yao et al., 2019, 2020), or other locations. In 2014 and 2016, more than 40 cultivars were propagated for cultivar trials at the NMSU Sustainable Agriculture Science Center, the NMSU Agricultural Science Center in Los Lunas, NM, and the NMSU Leyendecker Plant Science Center in Las Cruces, NM (Yao and Heyduck, 2018; Yao et al., 2019, 2020). Because each cultivar had limited plants, grafting take rates were counted for all cultivars together instead of per cultivar. The sample sizes ranged from 100 to 400 from 2011 to 2020.

Weather data were collected from mid-April to the mid-June from 2011 to 2020, at the NMSU Sustainable Agriculture Science Center.

\section{Results and discussion}

Grafting DATE. Mid to late May comprised a favorable window for jujube grafting in northern New Mexico. If grafting happened early (first week of May), then partially active (slip) cambium layers occurred, which made bark grafting difficult but did not affect whip/tongue grafting. In 2020 , late grafting in mid-June took well but did not grow well. Wu et al. (2018) reported that 17 Apr. was the best time among the three grafting dates of 6 Apr., 17 Apr., and 2 May in Shijiazhuang, Hebei, China. Suitable grafting times varied from location to location (Li, 2009; Wang, 2014). Areas with long growing seasons had a longer grafting window than areas with shorter growing seasons.

GRAFTING TAKE RATE AND WEATHER CONDITIONs. Grafting success depended on the grafting techniques and weather conditions. Normally, scionwood buds sprouted 7 to $10 \mathrm{~d}$ after grafting. It could take much longer if the temperature stayed cool after grafting, as in 2019. Daily minimum temperatures from mid-April to midJune in Alcalde, NM, are presented in Fig. 2.

From 2011 to 2020 , during years with no frost after grafting (2011, 2012,2013 , and 2018), the grafting take rates were $90 \%$ to $100 \%$, with limited smaller plants (Table 1). Bark grafting and whip/tongue grafting

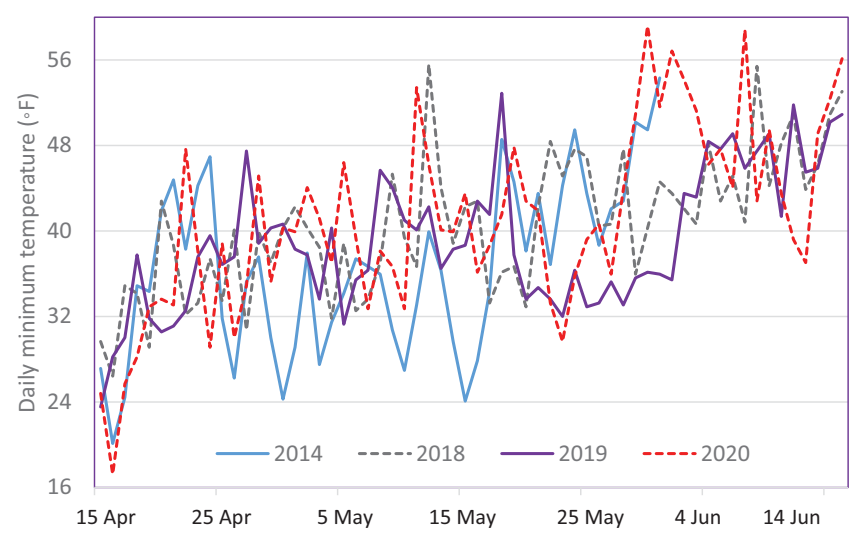

Fig. 2. Daily minimum temperatures from mid-April to mid-June in Alcalde, NM; $\left({ }^{\circ} \mathrm{F}-32\right) \div 1.8={ }^{\circ} \mathrm{C}$. 
Table 1. Jujube grafting success and marketable plant percentages in northern New Mexico in 2014, 2018, 2019, and 2020.

\begin{tabular}{lcccc}
\hline Yr & $\begin{array}{c}\text { Plants grafted } \\
\text { (no.) }\end{array}$ & $\begin{array}{c}\text { Marketable } \\
\text { plants }(\%)^{\mathbf{z}}\end{array}$ & $\begin{array}{c}\text { Small } \\
\text { plants (\%) }\end{array}$ & Mortality (\%) \\
\hline 2014 & 380 & 86 & 5.0 & 9.0 \\
2018 & 450 & 93 & 2.0 & 5.0 \\
2019 & 240 & 80 & 5.0 & 15.0 \\
2020 & 220 & 30 & 20 & 50.0
\end{tabular}

${ }^{\mathrm{z}}$ Marketable plants $=$ height $>3 \mathrm{ft}$ with diameter above graft union $\geq 1 / 2$ inch; small plants $=$ height $1-3 \mathrm{ft} ; 1$ $\mathrm{ft}=0.3048 \mathrm{~m}, \mathrm{l}$ inch $=2.54 \mathrm{~cm}$. performed equally well. Because of the nature of the rootstocks, cleft grafting was only used during one season, 2017, when rootstocks were larger.

Low temperatures had a critical role in grafting success. Frost events before and after grafting consistently caused graft failure (Table 1, Fig. 2). In 2020 , a temperature of $29.5^{\circ} \mathrm{F}$ on 23 May killed the rootstock cambium layer and bark, greatly reducing the grafting take rate. With a damaged cambium layer for rootstock and scionwood, $50 \%$ of grafted plants did not take. Among those that did take, $20 \%$ of them did not heal properly and ended as smaller plants in 2020 . The 50 plants grafted in mid-June took, but they ended as thin and small plants in 2020. In 2019, the minimum temperature was between 32 and $36{ }^{\circ} \mathrm{F}$ for 2 weeks from 20 May to early June (Fig. 2), which delayed scionwood sprouting and reduced the grafting take rate (Table $\mathrm{l}$ ).

In 2014, there were repeated, severe late frosts (late April to midMay) (Fig. 2) before grafting that killed the rootstock cambium layer and bark (Fig. 3). Grafting was delayed 2 weeks to late May/early June. With some partially damaged rootstocks, the grafting success rate was reduced, resulting in some smaller plants (Table 1 ).
There were four grafting scenarios in 2014 (Fig. 3): a) a damaged cambium layer and split bark, resulting in no grafting performed; b) partially damaged cambium layer, resulting in the graft not taking and suckers generated underneath; c) the graft took, resulting in branchlets only and no new shoots; and d) normal, the graft took, resulting in satisfactory growth.

Based on those data, it is recommended to graft when the threat of frost has passed in areas with short growing seasons. Otherwise, grafting failure and a high percentage of smaller and weaker plants are likely.

Pinching BRANChlets to STIMULATE NEW SHOOTS. Occasionally, grafts succeeded, but only branchlets emerged without new shoots. Without intervention, only a few strong woody branchlets resulted. Continued pinching of branchlets could stimulate new shoot emergence (Fig. 4). In other literature, this technique was also mentioned along with pinching of the main shoots and side branches to stimulate early fruit production (Chai et al., 2016; He et al., 2013; Ma et al., 2019).

Cultivar growing habits in THE NURSERY. During the grafting year, the Li group cultivars, $\mathrm{Li}$, Shanxi

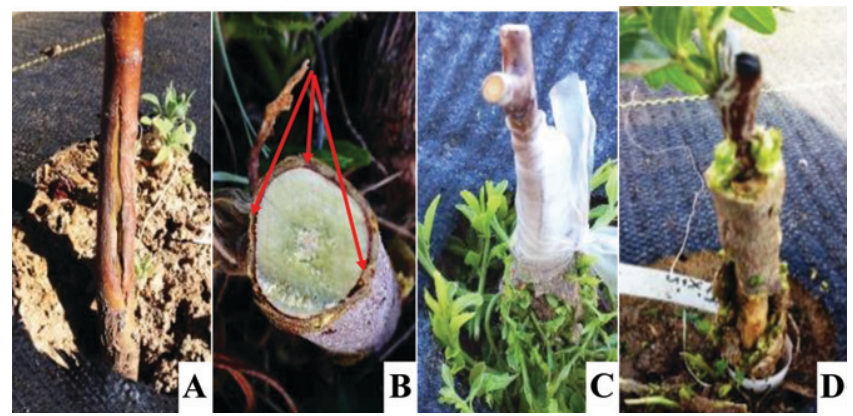

Fig. 3. Damaged jujube rootstocks and scionwood after repeated frosts in 2014: (A) split bark; (B) damaged cambium layer and bark; (C) graft did not take and generated numerous suckers on rootstock; (D) graft partially took, with branchlets only, numerous suckers (removed), and detached bark on the rootstock.

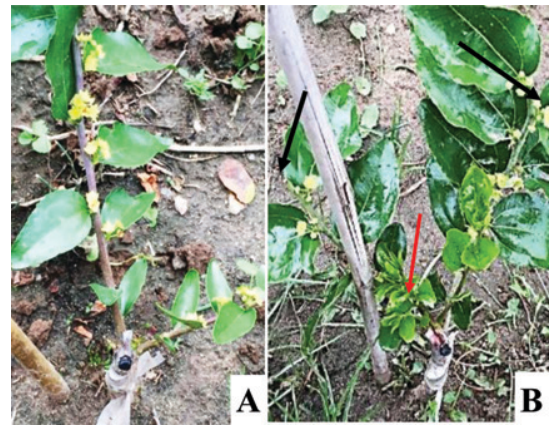

Fig. 4. After jujube grafting, pinching branchlets stimulated new shoot growth: (A) before and (B) after pinching (black arrows) and new shoot emerging (red arrow).

$\mathrm{Li}$, and Redland, typically had taller and larger plants than others. The cultivars Honeyjar, Fucuimi, and Russian 2 were relatively shorter than others. Plants of 'Lang' were shorter but welldeveloped compared with 'Li'. 'Kongfucui' also had strong nursery plants, and 'Maya' and 'Sugarcane' had relatively thinner plants. The cultivar Sihong had a lower grafting take rate than others, which could be because of its shoot/bud structure. 'Sihong' has strong and upright side branches, but its buds might not be as fully developed as other cultivars. Both scionwood and bud quality should be determined before grafting for 'Sihong'.

Because long side branches are not desired in nursery plants, pinching secondary branches after three nodes can reduce nutrient loss and enhance the retained sections. Large nurseries often remove all side branches to ease operation and shipping in the fall. Retaining one or two nodes for those side branches $2 \mathrm{ft}$ aboveground is recommended, especially for those nurseries targeting local markets.

In summary, frosts before and after grafting greatly impact grafting success and subsequent plant growth. Grafting time can be delayed to avoid frosts and ensure that the rootstocks are healthy. If frosts do occur after grafting, then graft failure or a high percentage of smaller plants may result. Pinching branchlet tips after grafting can stimulate new, desirable shoot development.

\section{Literature cited}

Chai, F., X. Fu, Y. Shi, and J. Zhang. 2016. Productive cultural management 
techniques of grafted Huizao in grafting year. Xinjiang Farm Res. Sci. Technol. 4:10-11. (in Chinese).

Guo, Y. and G. Shan. 2010. The chinese jujube. Shanghai Sci. Tech. Pub., Shanghai, China. (in Chinese).

Guo, Y., B. Wang, and S. Yao. 1994. Jujube grafting and management techniques in nursery. Deciduous Fruits 1:30-32. (in Chinese).

He, G., F. Wang, and L. Shen. 2013. Grafting propagation techniques for jujube cv. Huizao. Modern Agr. 12:12-13. (in Chinese).

Johnstone, R. 2020. Propagating jujubes. 27 July 2021. <https://www.agric.wa.gov. au/minor-fruits/propagating-jujubes? nopaging $=1>$.

Li, K. 2009. Comparison of jujube topwork grafting methods. J. Hebei For. Sci. Technol. 2009(4):9-10. (in Chinese).

Ma, Y., G. Li, and Y. Jie. 2019. Culture managements for grafted high density hui- zao on directly seeded rootstocks. Xinjiang Farm Res. Sci. Technol. 2009(4):22-23. (in Chinese).

Shi, M., S. Yang, and X. Liang. 2006. Research on reproduction and graftingbreeding techniques of sour jujube kernels. For. Sci. Technol. 31(5):62-63. (in Chinese).

U.S. Department of Agriculture. 2008. Soil survey of Rio Arriba area, New Mexico, parts of Rio Arriba and Sandoval counties. 26 July 2021. <https://www.nrcs.usda. gov/Internet/FSE_MANUSCRIPTS / new_mexico/NM650/0/Rio\%20Arriba $\% 20$ Area\%20NM.pdf $>$.

Wang, X. 2014. Early cropping management techniques for grafted jujube cultivar Dapingding on sour jujubes in place. Northern Fruits 2014(3):42-43. (in Chinese).

Wu, S., F. Zhi, and Y. Jia. 2018. Effects of different grafting times and scion types on survival rate and growth potential of Ziziphus jujuba cv. Zaocuiwang. J. Hebei Agr. Sci. 22(6):47-50. (in Chinese).
Yao, S. 2013. Past, present, and future of jujubes - Chinese dates in the United States. HortScience 48:672-680, https:// doi.ort/10.21273/HORTSCI.48.6.672.

Yao, S. 2014. Jujube (Ziziphus jujuba) grafting. New Mexico State Univ. Coop. Ext. Serv. Publ. H335. 20 Aug. 2021. $<$ https://aces.nmsu.edu/pubs/_h/H335. pdf $>$.

Yao, S. and R. Heyduck. 2018. Ornamental jujube cultivar evaluation in the southwestern United States. HortTechnology 28:557-561, https://doi.org/10.21273/ HORTTECH04073-18.

Yao, S., R. Heyduck, and S. Guldan. 2019. Early performance of jujube fresh eating cultivars in the southwestern United States. HortScience 54:1941-1946, https://doi. org/10.21273/HORTSCI14312-19.

Yao, S., R. Heyduck, S. Guldan, and G. Sapkota. 2020. Early performance of drying and multipurpose jujube cultivars in the southwestern United States. HortScience 55:1804-1810, https://doi.org/ 10.21273/HORTSCI15344-20. 